\title{
Morphoanatomical Studies of Tiliacora racemosa Colebr.
}

\author{
Yogeshwari C
}

Department of Botany, Nirmala College for Women, India

Received October 30, 2019; Revised December 28, 2019; Accepted December 30, 2019

Copyright $\bigcirc 2020$ by authors, all rights reserved. Authors agree that this article remains permanently open access under the terms of the Creative Commons Attribution License 4.0 International License

\begin{abstract}
Tiliacora racemosa is a climbing shrub belonging to the family Menispermaceae and is used in traditional medicine for treating different ailments such as snakebites, cuts and wounds, strangury and also used as a diuretic. The morphoanatomical studies help to identify diagnostic features for the identification and standardization of the medicinal plant. The plant material was fixed, sectioned using rotary microtome and stained with toluidine blue. The leaf consists of very thick midrib with small lateral veins both being plano-convex. The midrib consists of three top or egg shaped collateral vascular bundles which are surrounded by a common sclerenchymatous bundle sheath and the lamina is dorsiventral. The adaxial epidermis is apostomatic and the abaxial epidermis is stomatiferous which is of cyclocytic type. The stem is circular in sectional view and consists of about 19 discrete wedge shaped vascular bundles. The narrow and wide fibres, vessel elements were seen in powder microscopy. Wide fibres, vessel elements were seen in powder microscopy.
\end{abstract}

Keywords Tiliacora racemosa, Morphoanatomy, Cyclocytic

\section{Introduction}

India is rich in traditional knowledge and traditional healers use different parts of medicinal plants as medicine [1]. However, the major drawback to the use of herbal medicine is the lack of standardization. This paves way for wrong identification, unintended substitution of closely related species and intended adulteration of genuine drugs with quality less ones to meet the increasing demands of the herbal drugs [2]. Furthermore, herbal drugs are likely to decomposition, contamination and variation in composition of constituents, which gives rise to little or no therapeutic efficacy [3]. It is therefore necessary to evaluate qualitative and quantitative parameters that may be useful in preventing adulteration of the crude herbs and its formulations [4].

The family Menispermaceae commonly known as Moonseed family [5] comprises 71 genera and approximately 520 species [6]. Tiliacora racemosa is a climbing shrub belonging to the family Menispermaceae and is commonly known as Perunkattukkodi in Tamil. The plant has been utilized ethnobotanically for treating cuts and wounds [7], snakebite [8,9], strangury and also used as a diuretic [10]. The plant has also been used in many Ayurvedic preparations [11]. Various phytochemical investigations have also been carried out resulting in isolation and identification of esters [12] and bisbenzylis oquinoline alkaloids [13].

Despite the wide use of $T$. racemosa, there is a lack of thorough pharmacognostical data on its structural anatomy which is required for the proper identification and standardization of the herbal product. This study was therefore undertaken to develop standards for Tiliacora racemosa by carrying out morphoanatomical studies of the leaf and stem of the plant.

\section{Materials and Methods}

\subsection{Collection of Specimens}

The plant specimen for the proposed study was collected from Guruvareddiyur section, Chennampatti range, Western Ghats, Tamil Nadu, India. The collected plant was identified with the help of Flora [14] and authenticated by the Botanical Survey of India (Southern circle), Coimbatore. The voucher number of the specimen is BSI/SRC/5/23/2016/Tech./1521. The required samples of different organs were cut and removed from the plant and fixed in FAA (Formalin-5ml+ Acetic acid-5ml $+70 \%$ Ethyl alcohol-90ml). After $24 \mathrm{hrs}$ of fixing, the specimens were dehydrated with graded series of tertiary-butyl alcohol [15]. Infiltration of the specimens was carried by gradual addition of paraffin wax (melting point 58-60 C) until tertiary-butyl alcohol solution attained super saturation. The specimens were cast into paraffin blocks. 


\subsection{Sectioning}

The paraffin embedded specimens were sectioned with the help of rotary microtome. The thickness of the sections was 10-12 $\mu \mathrm{m}$. Dewaxing of the sections was by customary procedure [16] and the sections were stained with Toluidine blue [17]. Since toluidine blue is a polychromatic stain, the staining results were remarkably good and some cytochemical reactions were also obtained. The dye rendered pink colour to the cellulose walls, blue to the lignified cells, dark green to suberin, violet to the mucilage, blue to the protein bodies etc. The sections were also stained with safranin and fast-green wherever necessary.

For studying the stomatal morphology, venation pattem and trichome distribution, paradermal sections (sections taken parallel to the surface of leaf) as well as clearing of leaf with $5 \%$ sodium hydroxide or epidermal peeling by partial maceration employing Jeffrey's maceration fluid [15] were prepared. Glycerine mounted temporary preparations were made for macerated/cleared materials. Powdered materials of different parts were cleared with sodium hydroxide and mounted in glycerine after staining. Different cell components were studied and measured.

\subsection{Photomicrographs}

Microscopic descriptions of tissues are supplemented with micrographs wherever necessary. Photographs of different magnifications were taken with Nikon lab photo 2 microscopic unit. For normal observations, bright field was used and for the study of crystals, starch grains and lignified cells, polarized light was employed since these structures have birefringent property and under polarized light they appear bright against dark background. Magnifications of the figures are indicated by the scale-bars. Descriptive terms of the anatomical features are as given in the standard Anatomy books [18].

\section{Results}

\subsection{Morphoanatomy of Leaf}

Tiliacora racemosa (Fig. 1) has simple leaves with alternate phyllotaxy, ovate to lanceolate shaped, glabrous, acuminate at apex and obtuse or cordate at base. It is prominently reticulate veined with undulate margin.

The leaf consists of very thick midrib with small lateral veins (Fig. 2 a, b). The main midrib is plano-convex in sectioned view, with slightly raised adaxial side and thick and wide abaxial part. The midrib is $730 \mu \mathrm{m}$ thick and 620 $\mu \mathrm{m}$ wide and consists of a thick epidermal layer of small thick walled cells. The ground tissue is homogenous and parenchymatous. The cells are angular, thin walled and compact. The vascular system consists of three top or egg shaped collateral vascular bundles which are surrounded by a common sclerenchymatous bundle sheath. The vascular bundles have adaxially directed protoxylem and abaxial larger metaxylem. The xylem elements are circular, thick walled and compact. The metaxylem elements are $40 \mu \mathrm{m}$ wide. Arc shaped phloem elements which include small thick walled densely strained sieve elements occur on the outer lower ends of the vascular bundles.

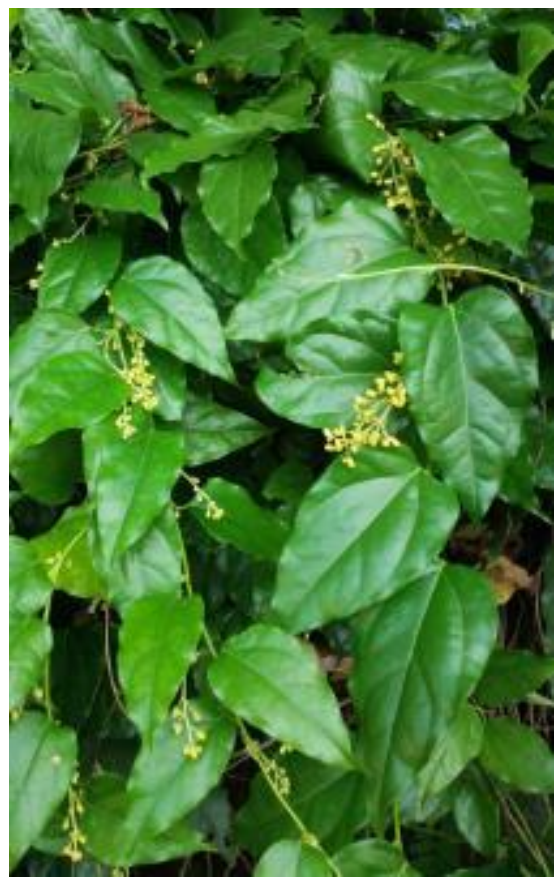

Figure 1. Vegetative and reproductive apical branches of Tiliacora racemosa

The lateral vein is also plano-convex in sectioned view with flat adaxial side and thick conical abaxial side (Fig.2 c). It is $750 \mu \mathrm{m}$ thick and $550 \mu \mathrm{m}$ wide and consists of thick walled small epidermal cells, parenchymatous ground tissue and large collateral strand ensheathed by sclerenchymatous layer. The lamina is dorsiventral with adaxial palisade layer and abaxial spongy parenchyma zone. The adaxial epidermis consists of wide, thin walled cells and thin elongated epidermal cells on the abaxial side. The palisade tissue includes single, short horizontal layer of columnar cells. The spongy parenchyma has sponge cells with wide air-spaces. The lamina is $100 \mu \mathrm{m}$ thick. These are fairly thick lateral veins which are slightly raised above leaf surface and possess small collateral vascular tissues within thick sclerenchymatous sheath. There are also smaller, circular vascular strands which possess a small cluster of vascular bundle and thick sclerenchymatous bundle sheath (Fig. 2d). 


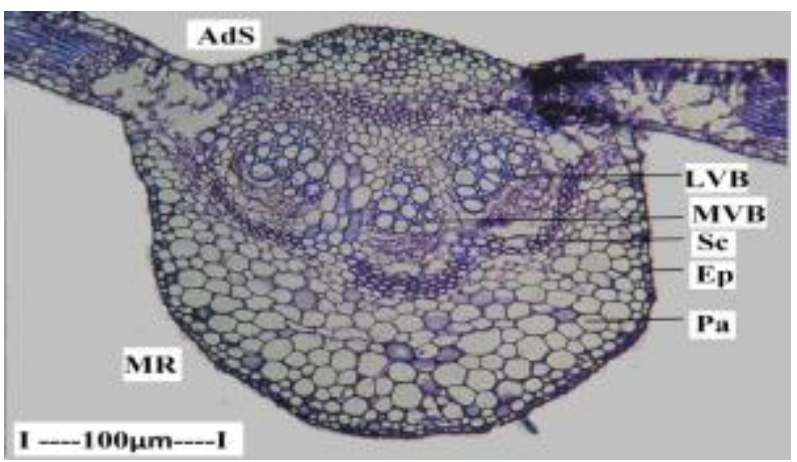

(a)

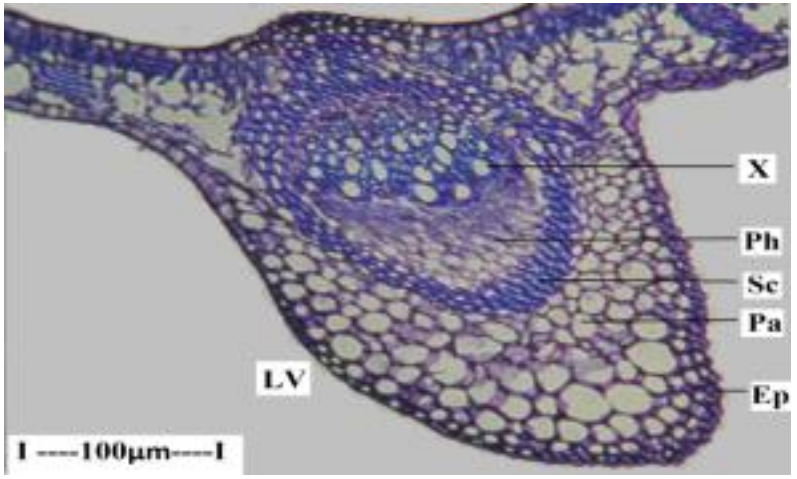

(c)

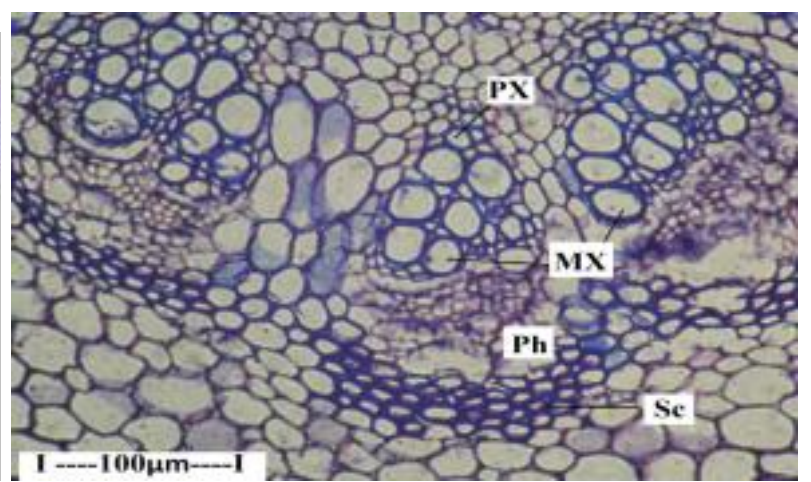

(b)

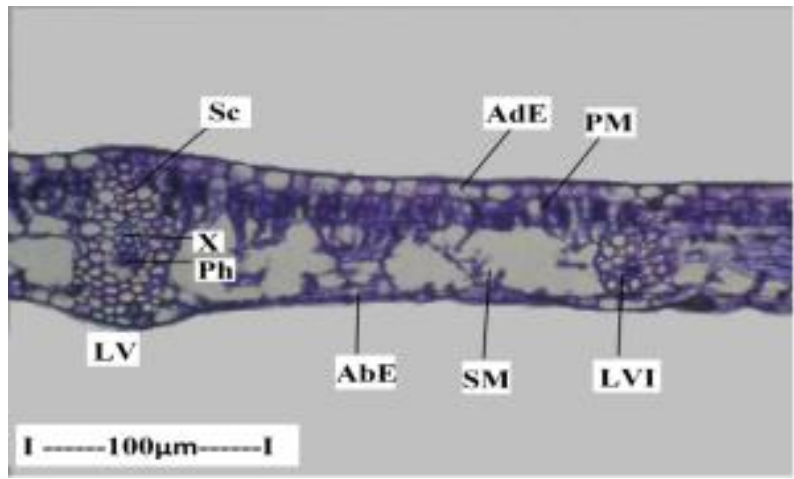

(d)

Figure 2. Anatomy of Tiliacora racemosa leaf: (a) - T.S. of leaf through midrib, (b) - A portion of enlarged, (c) - T.S. of leaf through thick lateral view, (d) - T.S. of lamina with smaller lateral veins. MR: midrib; Ep: epidermis; AbE: abaxial epidermis; AdE: adaxial epidermis; Pa: par enchymatous ground tissue; Sc: sclerenchyma; LVB: lateral vascular bundle; MVB: median vascular bundle; X: xylem; PX: protox ylem; MX: metaxylem; Ph: phloem; LVL: lateral veinlet; PM: palisade mesophyll; SM: spongy mesophyll; LV: lateral vein

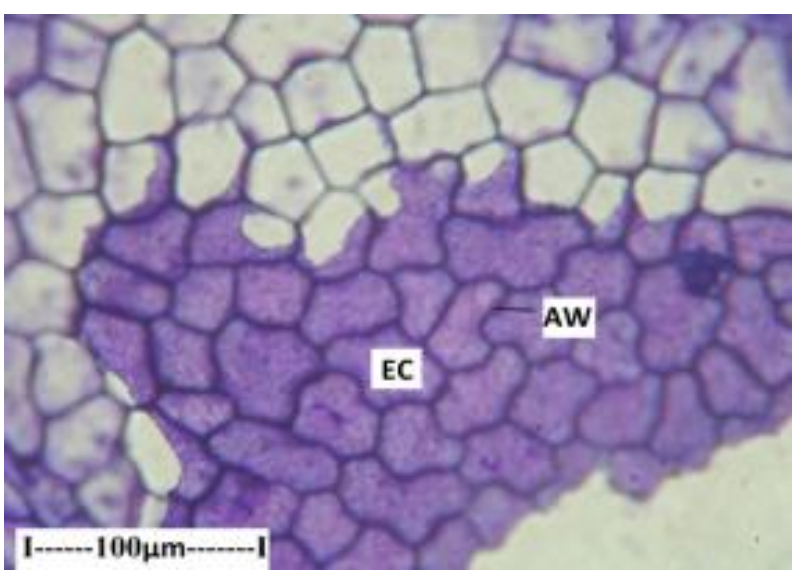

(a)

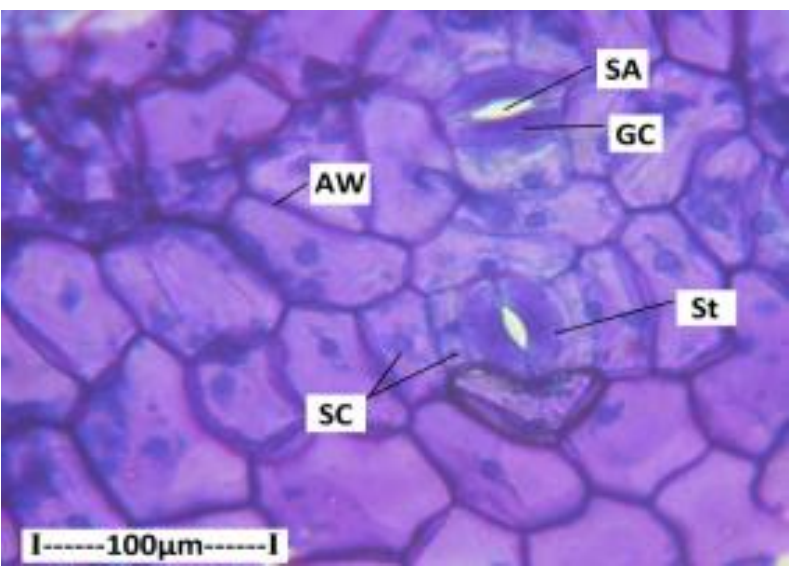

(b)

Figure 3. Epidermal tissue and stomata, (a)- Paradermal section of adaxial epidermis (b)- Paradermal section of abaxial epidermis. AW: anticlinal walls; EC: epidermal cells; St: stomata; SA: stomatal aperture; GC: guard cells; SC: subsidiary cells

\subsubsection{Epidermal Tissue and Stomata}

In paradermal sectional view, the lamina exhibits epidermal cells and stomata. The epidermal cells are polyhedral with thick and straight anticlinal walls. The cells have prominent nucleus. The adaxial epidermis is apostomatic i.e., without stomata (Fig. 3 a). The anticlinal walls are slightly wavy. The abaxial epidermis is stomatiferous. The stomata are sparsely distributed (Fig. 3 b). The guard cells are elliptical and have small polar nodules. The stomata are $30 \mu \mathrm{m}$ thick and $40 \mu \mathrm{m}$ long. The stomatal pore is prominent. The stomata are of cyclocytic type. The stoma is encircled by four or five rectangular cells which surrounds the guard cells.

The venation of the lamina is densely reticulate. The 
veins include the lateral veins and thin veinlets. They form polygonal areas called vein-islets. The veinlets are enclosed by thick and distinct boundaries. Within veinis lets are seen vein terminals which extend into the veinislets. These vein terminals are called vein terminations. The vein terminations are mostly simple or unbranched or occasionally they are forked at the tip.

\subsection{Morphoanatomy of Stem}

The stem is circular in sectional view which measures $1.9 \mathrm{~mm}$ in diameter. The stem consists of a single layer of thick walled small epidermal cells which is followed by wide, homogenous zone of parenchymatous cells (Fig. 4 a, b). The vascular systemconsists of about 19 discrete wedge shaped vascular bundles. The intervascular medullary zone consists of radially stretched spindle shaped parenchyma cells.

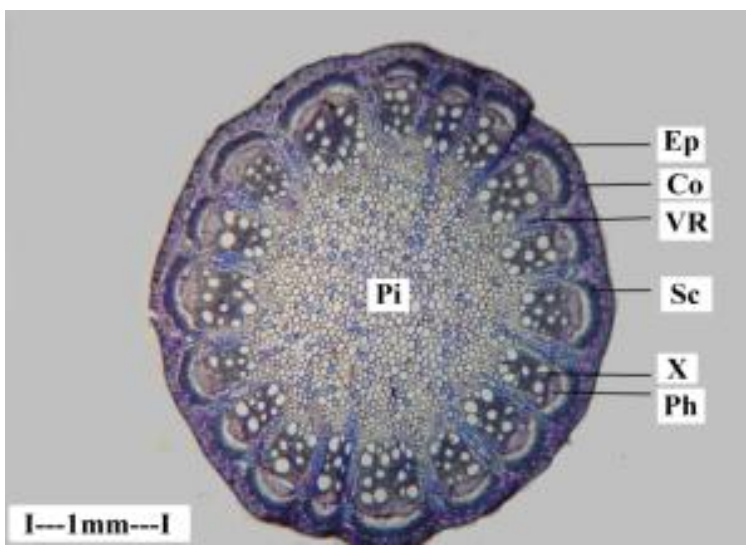

(a)

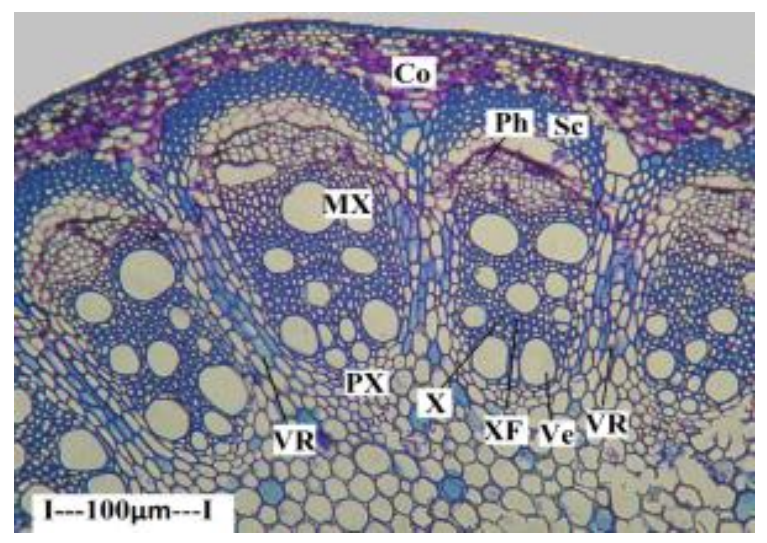

(b)

Figure 4. Anatomy of stem, (a) - T.S. of stem - entire, (b) - A sector enlarged. Ep: epidermis; Co: cortex; Sc: sclerenchyma; X: xylem; PX: protoxylem; MX: metaxylem; XF: xylem fibres; Ve: vessel; Ph: phloem; VR: vascular ray; Pi: pith
The vascular bundles consist of wide, circular thin walled metaxylem vessels and narrow protoxylem elements. The metaxylem elements are $80 \mu \mathrm{m}$ wide. The vessels are embedded in small thick walled and lignified fibres. On the outer part of the vascular bundles are situated thick, semi-circular phloem elements. The outer phloem elements are crushed into thin dark layer and only the inner elements are intact. The phloem elements are small, angular, thin walled cells arranged in compact parallel lines. The pith is wide and comprises uniformly angular and compact parenchyma cells. No specific inclusions are within pith cells.

\subsection{Powder Microscopy}

The powder preparations of the plant exhibit some specific and characteristic inclusions which are presented in Fig. 5. Xylem fibres are abundant in the powder (Fig. 5 a). There are two types of fibres in the powder. Some are thin and narrow with walls and narrow lumen which are $1.2 \mathrm{~mm}$ long and $5 \mu \mathrm{m}$ thick. The wide fibres are less frequent and they have thin walls and wide lumen. They have two or more septa. The lumen is filled with granular contents and is $240 \mu \mathrm{m}$ long and $8 \mu \mathrm{m}$ wide. The parenchyma cells are long, rectangular and thin walled. They are either solitary or oriented into two cells. The cells are $70-170 \mu \mathrm{m}$ long and $30-50 \mu \mathrm{m}$ wide. The cells may have some inclusions.

The powder consis ts of different types of ves selelements which are either short and wide (Fig. 5 b) or long or narrow (Fig. 5 c). The wide vessel elements have short, pointed tails at the end. At end walls of the vessel elements occur wide, circular and horizontal perforations. On the lateral walls are seen prominent, multiseriate and alternate bordered pits. The narrow long vesselelement has elliptical and oblique wall perforations. The wide vesselelements are $250-280 \mu \mathrm{m}$ long and $70-80 \mu \mathrm{m}$ wide. The long narrow vessel elements are $260 \mu \mathrm{m}$ long and $40 \mu \mathrm{m}$ wide. Small fragments of epidermal peelings of the stem are occasionally seen in the powder (Fig. 5 d). The peeling consists of squarish to polygonal cells with thick and straight anticlinal walls. The cells have some spherical bodies. The cells are $60 \times 70 \mu \mathrm{m}$ in size.

(c) - T.S. of leaf through thick lateral view, (d) - T.S. of lamina with smaller lateral veins. MR: midrib; Ep: epidermis; AbE: abaxial epidermis; AdE: adaxial epidermis; Pa: parenchymatous ground tissue; Sc: sclerenchyma; LVB: lateral vascular bundle; MVB: median vascular bundle; X: xylem; PX: protoxylem; MX: metaxylem; Ph: phloem; LVL: lateral veinlet; PM: palisade mesophyll; SM: spongy mesophyll; LV: lateral vein 


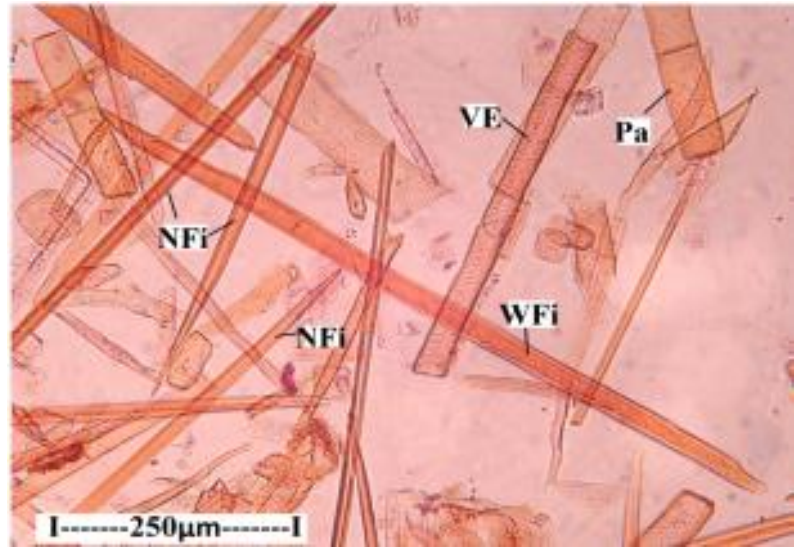

(a)

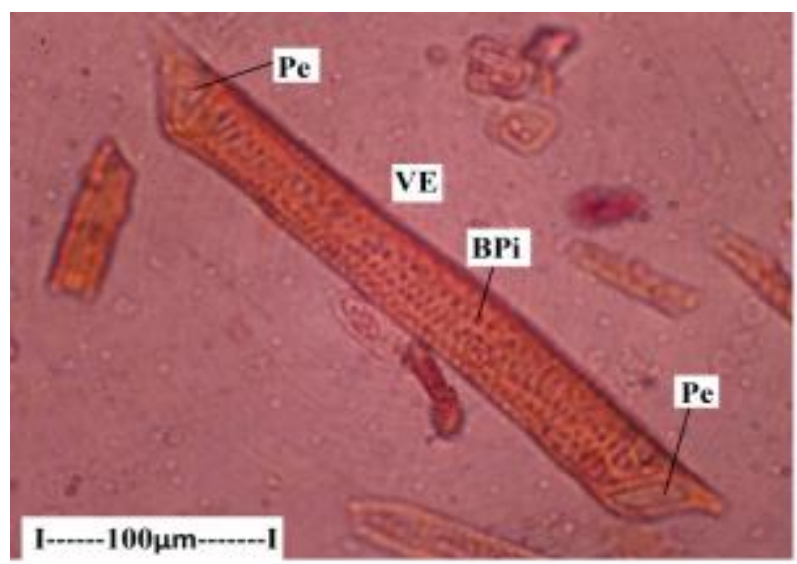

(c)

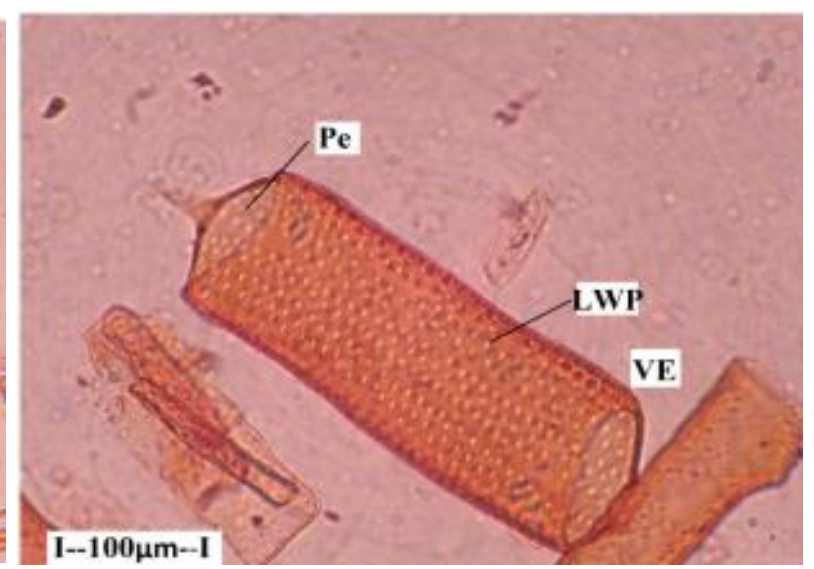

(b)

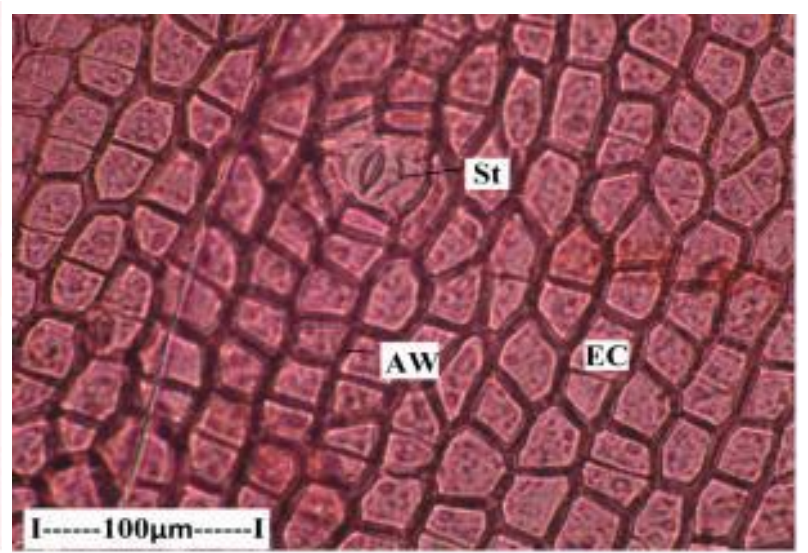

(d)

Figure 5. Powder microscopy (a) Fibres and vessel elements, (b) Wide short vessel elements showing end wall perforation and lateral wall bordered pits (c) Long narrow vessel element with oblique end wall perforation, (d) Epidermal peeling of the stem in surface view. Pa: parenchyma cells; VE: vessel element; NFi: narrow fibres; WFi: wide fibres; Pe: perforation at end walls; LWP: lateral wall pits; Bpi: bordered pits; AW: anticlinal walls; EC: epidermal cells; St: stomata

\section{Discussion}

The mciroscopical characteristics of the plant species can be used to distinguish the species even when it is fragmented. The detailed studies of the anatomy of the Menispermaceae revealed the relative uniformity particularly with regard to the peculiar medullary rays which separate the vascular bundles and present as distinctive features in the transverse sections of the plant parts and also with regard to the xylem which is characterized by large and conspicuous vessels [19, 20]. The organization of the median rib of Tiliacora racemosa is similar to the other species of Menispermaceae, i.e., it is of collateral type surrounded by sclerenchyma fibers resembling an arc [21].

The stomata are of cyclocytic type which is in agreement with the data obtained from the previous studies of the plant [22] whereas anomocytic stomata were observed by Kundu and Guha [23]. The vessel elements of Menispermaceae range from small $(50-100 \mu \mathrm{m})$ to medium $(100-200 \mu \mathrm{m})$ and the results of the present investigation coincides with this in which the vessel elements are of 70-80um. In Tiliacora racemosa, perforations occur at the end of the vessel elements as in many members of Menispermaceae [20].

The presence of fibres, vessels, parenchyma cells and fragments of epidermal cells in the present powder microscopical studies served as the distinguishing microscopic characteristics and specific anatomical markers. In the present study, no foreign material was detected in the fine powder of the plant which corroborates with the previous studies of Aegialitis rotundifolia [24] WHO [25] has also recommended that the herbal materials should not contain any foreign matters such as moulds, insects and any other animal contamination including excreta of animals or insects.

\section{Conclusions}

Macroscopical studies revealed that Tiliacora racemosa has simple leaves with alternate phyllotaxy, ovate to lanceolate, acuminate at apex, obtuse or cordate at base, glabrous with undulate margin. It is prominently reticulate veined with a circular stem. Anatomical studies revealed 
that the adaxial epidermis was apostomatic whereas abaxial epidermis was with cyclocytic type of stomata. The young stem showed the presence of 19 wedge shaped vascular bundles with broad primary medullary rays which is a characteris tic feature of Menispermaceae. The results of the present study will contribute to the authentic identification of this species and support quality control tests to prevent adulteration in herbal medicines.

\section{Acknowledgements}

The author is thankful to Dr. P. Kumudha, Associate Professor (Retd.), Vellalar College for Women, erode for her valuable guidance and Prof. P. Jayaraman, Director, Plant Anatomy Research Centre, Chennai for providing necessary facilities to carry out this work.

\section{REFERENCES}

[1] S. Evelyne Priya, R. Ravindhran. Pharmacognostical characterization of Phyla nodiflora L. (verbenaceae): a valuable medicinal plant. Asian Journal of Pharmaceutical and Clinical Research, 8(3): 256-26, 2015.

[2] M. F. Baidoo, E.Asante-Kwatia, A. Y. Mensha, G.H. Sam, I. K. Amponsah. Pharmacognostic characterization and development of standarzation parameters for the quality control of Entada africana Guill. Perr. Journal of Applied Research on Medicinal and Aromatic plants, 12: 36-42, 2019.

[3] I. Aslam, M.F. K. Afridi. Pharmacognostic characterization of Beaumontia grandiflora (Roxb.) Wall. leaf for taxonomic identification for quality control of a drug. Journal of Applied Research on Medicinal and Aromatic plants, 8: 5359, 2018.

[4] K. P. Satyendra, N. S. Alakh, S. Hemalatha. Cytomorphological and physicochemical evaluations of Cryptocoryne spiralis. Journal of Herbs, Spices and Medicinal plants, 18: 304-317, 2012.

[5] C. O. Rosa del, A. K. Elizabeth, V. D. W Henk. Molecular phylogeny of the moonseed family (Menispermaceae): Implications for morphological diversification. American Journal of Botany, 94(8): 1425-38, 2007.

[6] N. Tamaio, A. Joffily, J. M. Alvarenga Braga, K. S. Rajput. Stem anatomy and pattern of secondary growth in some herbaceous vine species of Menispermaceae. Journal of Torrey Botanical Society, 137(2): 157-65, 2010.

[7] H. Renjini, V. Thangapandian, Binu Thomas. Ethnomedicinal knowledge of tribe-Kattunayakans in Nilambur forests of Malappuram District, Kerala, India. International Journal of Phy totherapy, 5(2): 76-85, 2015.

[8] N. Savithramma, P. Yugandhar, D. Suhrulatha. Traditional medicinal plants used by local people of Kailasakona- a sacred grove of Chittoor district, Andhra pradesh, India. International Journal of Pharmacy and Pharmaceutical
Sciences, 7(3): 407-11, 2015.

[9] V. Madhu, D. S. Ravindra Naik. Ethnomedicinal uses of leaf preparations in Adilabad district, Andhra pradesh, India. Ethnobotanical Leaflets, 13: 1337-47, 2009.

[10] D. C. Pal, S. K. Jain. Tribal Medicine, 1st ed, Naya Prokash, Calcutta, 1998.

[11] K. R. Kritikar, B. D. Basu. Indian Medicinal Plants, 1st ed, International Book Distributors, Dehradun, 2006.

[12] S. Joseph Selvaraj, I. Alphonse, S. John Britto. Isolation and characterization of novel esters from aerial parts of Tiliacora acuminata. Indian Journal of Chemistry - Section B Organic Medicinal Chemistry, 48(7): 1038-40, 2009.

[13] K. P. Guha, P. C. Das, B. Mukherjee. Structure of Tiliamosine: A new diphenyl bisbenzylisoquinoline alkaloid from Tiliacora racemosa. Tetrahedron Letters, 17(47): 4241-44, 1976.

[14] J. S. Gamble. Flora of the Presidency of Madras, 1st ed, Neeraj Publishing House, Delhi, 2014.

[15] J. E. Sass. Elements of Botanical microtechnique, McGraw Hill Book Corporation, New York, 1940.

[16] D. A. Johansen. Plant microtechnique, McGraw Hill Book Corporation, New York, 1940.

[17] T. P. O'Brien, N. Feder, M. E. McCully. Polychromatic staining of plant cell walls by toluidine blue $\mathrm{O}$, Protoplasma, 59: 367-373, 1964.

[18] K. Easu. Plant anatomy, John Wiley and sons, New York, 1964.

[19] C. R. Metcalfe, L. Chalk. Anatomy of the Dicotyledons, Vol. I, Oxford University Press, Oxford, 1979.

[20] Carlquist and Sherwin. Wood and stem anatomy of Menispermaceae, Aliso, 14(3): 155-70, 1995.

[21] H. D. Wet, P. M. Tilney, B. E. V. Wyk. Vegetative morphology and anatomy of Cissampelos in South Africa, South African Journal of Botany, 68: 181-190, 2002.

[22] H. P. Wilkinson. Leaf anatomy of the Menispermaceae tribe Tiliacoreae Miers, Botanical Journal of Linnean Society, 99: 125-74, 1989.

[23] B. C. Kundu, S. Guha. Tliliacora acuminata (Lam.) Miers, Bulletin of Botanical Survey of India, 17: 147-156, 1975.

[24] D. Ghosh, S. Mondal, K. Ramakrishna. Pharmacobotanical , physicochemical and phytochemical characterisation of a rare salt-secreting mangrove Aegialitis rotundifolia Roxb., (Plumbaginaceae) leaves: A comprehensive pharmacognostical study, South African Journal of Botany, 113: 212-229, 2017.

[25] WHO, Quality Control Methods for Herbal Materials. WHO Press, Geneva, 2011. 